\title{
Potential Benefits from the Utilization of Leucaena leucocephala in Thai Swamp Buffaloes Production
}

\author{
Jetana T \\ Research and Development Center for Livestock Production Technology \\ Faculty of Veterinary Science, Chulalongkorn University \\ Henri Dunant Street, Phathumwan, Bangkok 10330, Thailand \\ thongsuk.j@chula.ac.th
}

\begin{abstract}
This paper aims to comply four studies of using Leucaena leucocephala as feed supplement on Thai swamp buffaloes. These studies were conducted by the Research and Development Center for Livestock Production Technology, Faculty of Veterinary Science, Chulalongkorn University, Thailand. Leucaena is interesting forage which needs further study to investigate which technology is suitable to use it as a feed for swamp buffaloes. In this review, leaves of leucaena were used as a main feed ingredient in dietary supplement. The rain tree pods (RTP) dietary supplement containing high sugar enhanced microbial supply to the small intestine. On other the hand, rain tree pod also can be used as an appetizing material for combination with leaves of leucaena, mulberry and cassia. The low fibre digestibility in dietary supplement containing leucaena may be due to tannins contents. Sodium hydroxide $(\mathrm{NaOH})$ treatment and addition of polyethylene glycol (PEG) are ways to inactivate tannins contained in the leucaena. Toxicity of leucaena did not affect buffaloes, when appropriate proportion of leucaena to ruzi grass was fed. The mixed diet containing leucaena not more than $25 \%$ was the highest benefit for buffaloes as the mimosine+dihydroxypyridine (DHP) in the urine was less $100 \mathrm{mg} / \mathrm{kgBW}^{0.75}$. The high proportions of RTPP (rain tree pod pellets) in leucaena increased purine derivatives (PDs) and mimosine + DHP in the urine, but none the different proportions of RTPP affects to purine derivatives/digestible organic matter (PDs/DOMI) ratios. Several studies demonstrated the approach to use leucaena as the alternative feed supplement, to enhance the quality of feeds in swamp buffaloes production improvement. The practical implication of this review, is that it would be benefit for the smallholder farmers to use leucaena for their livestock, because it is not only to improve quality of feeds and reduce cost of feed, but also higher biodiversity results in a higher $\mathrm{N}$ retention in soils and a lower methane releases in the atmosphere.
\end{abstract}

Key Words: Leucaena leucocephala, Rain Tree Pod (Samanea saman), Rice Straw, Swamp Buffaloes

\section{INTRODUCTION}

Leucaena (Leucaena leucocephala) one of the multiple purpose trees has proven to be effective by improving nutrient utilization and nutrient intakes (Masafu \& Linington 2006), nutrient digestibility and animal performance (Shelton 2007; 2009) and lactation (Ghosh et al. 2007), also reducing the use of expensive concentrates (Jetana et al. 2011). There are several properties to consider leucaena a good fodder such as high crude protein content, content of essential elements except sodium $(\mathrm{Na})$, very high palatability, high digestibility, bypass protein contribution, anthelmintic properties. Nevertheless, animals fed leucaena, will obtain beneficial effect when leucaena toxicity can be solved (Shelton 2009). Leucaena contains mimosine (4-12\%), a toxic non-protein amino acid that found in genus of leucaena (Brewbaker \& Hylin 1965). Mimosine can be readily hydrolysed in the rumen to produce two toxic substances, 3,4-hydroxy-4 (1H)-pyridone $(3,4-\mathrm{DHP})$, a potent goitrogen (Hegarty et al. 1976) and 2,3-hydroxy-4 (1H)-pyridone (2,3-DHP). The mimosine toxicity is difficult to be seen, DHP toxicity is actually the main problem since DHP is goitrogen, disrupts endocine systems, suppressing thyroxine in blood. The DHP 
toxicity effect is cumulative and can take several months to appear. Toxicity symptoms occur when more than $30 \%$ of leucaena in diet and fed for an extended period (Shelton 2009). Symptoms of DHP toxicity can be divided into 2 patterns: 1) visible symptoms such as lethargy, hair loss, skin lesions, salivation, goitre and cataracts and 2) non- visible symptoms such as suppressed appetite, growth, low production and poor reproductive performance. Nevertheless, leucaena does not contain only mimosine as a toxic substance, but also contains tannins (2-6\%), particularly condensed tannins, that may affect protein metabolism in the rumen as well.

Thai farmers who raise buffaloes are not motivated to use leucaena because swamp buffaloes usually do not like to eat plant leaves, particulary leucaena leaves. It is totally different from goats (Shelton 2007). Therefore, limited success for adoption on the use of leucaena for buffaloes, particularly in Thai smallholder farms.

Leucaena generally can be used as a protein supplement for improvement of goats, beef cattle and dairy cows production in Thailand (Phaikaew et al. 2012, Jetana et al. 2010b). Usually, leucaena as fresh cut or sun-dried form is given to goats in cut and carry feeding systems. Sun-drying only helps to keep it last long, but sun drying does not alleviate the high anti-nutritional compounds found in this plant. Though, leucaena could be fed at the level $100 \%$ to goat, there is no sign of negative effects on animal health in Thailand (Phaikaew et al. 2012, Jetana et al. 2010a).

This paper aims to comply from 4 studies of using leucaena as a main feed ingredient for improving swamp buffaloes production in order to reinforce farmers to use leucaena, The studies has been continuously conducted by the Research and Development Center for Livestock Production Technology, Faculty of Veterinary Science, Chulalongkorn University, Thailand, since 2007-present.

The present objectives of this review are:

1. To determine the effects sun-dried leaves of leucaena compared with other leaves (mulberry and cassia) and ground rain tree pod (RTP) on whole tract digestibility of nutrients, $\mathrm{N}$ balance, urinary PDs excretion in Thai swamp buffaloes fed rice straw as a basal diet (experiment 1).

2. To find out the best treatment to inactive of tannins in leucaena leaves on whole tract digestibility of nutrients, $\mathrm{N}$ balance, urinary PDs excretion in Thai swamp buffaloes fed rice straw as a basal diet (experiment 2).

3. To investigate the effects of feeding different proportions of leucaena in mixed diets on purine derivatives and mimosine, 3, 4-DHP and 2,3-DHP in the urine (experiment 3).

4. To find out the best proportions of sun-dried rain tree pod pellets added into chopped fresh leucaena leaves as dietary supplements on urinary PDs excretion in Thai swamp buffaloes fed ammoniated rice straw as a basal diet (experiment 4).

In experiments 1, the use of cut and sun-dried leucaena leaves supplementation generally is not palatable to animals, particularly in buffaloes and cattle. Therefore, the animals will not eat them, suggesting that sun-dried leucaena leaves should be combined with appetizing materials such as molasses, cassava meal and maize etc. At present, those materials are very expensive, as a consequence of being used as an ingredient in producing bio-fuel. The mature rain tree pods (Samanea saman, RTP) are black-brown, oblong, lumpy, 10-20 cm long, 15-19 $\mathrm{mm}$ wide, ca. $6 \mathrm{~mm}$ thick, straight or slightly curved, and eventually cracking irregularly, and they are filled with a sticky, brownish pulp that is sweet and edible (Staples \& Elevitch 2006). Consequently, the characteristics of RTPs are probably suitable to be used as an appetizing material. These pods also contain high total sugar (18-30\%) and protein (16-30\%) (Jetana et al. 2007; 2008). Is it assumed that the pods can be used as both energy and protein supplements for animal production systems in tropical countries. Table 1 shows the composition of feed supplement of experiment 1 . 
Table 1. Composition of dietary supplements (kg/day/animal) in experiment 1

\begin{tabular}{lcccc}
\hline \hline & \multicolumn{4}{c}{ Supplement (kg on fed basis) } \\
\cline { 2 - 5 } & RTPP & LLRT & CLRT & MLRT \\
\hline Oven-dried rain tree pod (RTP) & 3.96 & 1.96 & 1.96 & 1.96 \\
Sun-dried leucaena leaves (LL) & - & 2.00 & - & - \\
Sun-dried cassia leaves (CL) & - & - & 2.00 & - \\
Sun-dried mulberry leaves (ML) & - & - & - & 2.00 \\
Premix & 0.04 & 0.04 & 0.04 & 0.04 \\
\hline
\end{tabular}

Premix contained (g/kg DM basis): 40,000,000 units vitamin A, 4,000,000 units vitamin D3, 40,000 units vitamin E, $0.02 \mathrm{~g}$ vitamin B12, $160 \mathrm{~g} \mathrm{Mn}, 240 \mathrm{~g} \mathrm{Fe}, 100 \mathrm{~g} \mathrm{Zn}, 20 \mathrm{~g} \mathrm{Cu}, 0.5 \mathrm{~g} \mathrm{Se}$, $2 \mathrm{~g}$ Co and $5 \mathrm{~g} \mathrm{I}$

\section{Effects on whole apparent digestibility and $\mathrm{N}$ balance}

The results of experiment 1 (Tables 2 ) show that the digestibility coefficients of DM (0.53-0.55) and OM (0.56-0.57) in swamp buffaloes fed different leaves of leucaena, mulberry, cassia, and oven-dried RTP as a dietary supplements were generally higher than those in animals fed ad libitum with rice straw alone (0.49-0.50), and there were no differences in the NDF digestibility (Jetana et al. 2006). The digestibility coefficients of NDF decreased in animals supplemented with RTP (0.38), possibly resulting from RTP which contained high available sucrose, more than the other supplements, therefore $\mathrm{pH}$ in the rumen may decrease (Jetana et al. 1998), the cellulolytic microbial activity might be constrained (Stewart 1977) and fibre digestion depressed (Hoover 1986; Ørskov 1986).

The N-balance (Table 2) decreased in buffaloes fed RTPP supplemental diet (218 $\mathrm{mgN} / \mathrm{kgBW}^{0.75}$ ) when comparing with the other supplements $(412,468$, and 431 $\mathrm{mgN} / \mathrm{kgBW}^{0.75}$ ). This was in contrast with Matras et al. (1991) and Howard et al. (2007), who reported an increase in $\mathrm{N}$-balance when a readily fermentable carbohydrate source was supplied to the rumen. The difference may be due to a shortage of rumen degradable protein (RDP) in RTPP supplemental diet. This demonstrated that animals fed LLRT, CLRT and MLRT supplemental diets improved utilization between carbohydrate and $\mathrm{N}$ compounds in the rumen, subsequently the faecal- $\mathrm{N}$ output decreased.

Though, the $\mathrm{N}$ intakes of all animal were similar, the $\mathrm{N}$-balance was the lowest and the faecal-N output was highest in animals supplemented with RTPP. It is possible that the heat and time of incubation is used for removing moisture and making fragile for RTP before grinding RTP into small pieces being too high or long. Therefore, heated sugar may be coated the protein from the pods and the structure of proteins become hard and subsequently this characteristics of ground oven-dried pods would be the protection of dietary protein from microbial attack in the rumen and hard to be digested in the small intestine by the enzymes. Thus, undegradable protein in pods is useless to the ruminal microbial and the host. While another possibility, it may imply that the rate of passage in animals fed RTPP supplemental diet is faster than in those fed the other supplemental diets, reflecting that excess un-fermentable $\mathrm{N}$ sources in the rumen was mostly fermented in the hindgut when animals fed diet containing high sugar content (Khalili \& Huhtanen 1991). This may be due to $\mathrm{N}$ compounds in the rumen getting attached to the condensed tannins and used by the rumen microbes in the animals' RTPP supplemental diet, therefore the faecal-N output was less when compared with animals fed LLRT, CLRT, and MLRT supplemental diets. 
Table 2. Intakes of DM, OM, and NDF and the digestibility coefficients of DM, OM, and NDF and $\mathrm{N}$ balance in Thai, swamp buffaloes fed a based diet of rice straw supplemented with different protein-rich leaves

\begin{tabular}{|c|c|c|c|c|c|}
\hline & \multicolumn{5}{|c|}{ Supplements (kg on fed basis) in experiment 1} \\
\hline & RTPP & MLRT & CLRT & LLRT & SED \\
\hline Number of animals & 4 & 4 & 4 & 4 & \\
\hline $\mathrm{BW}(\mathrm{kg})$ & $265 \pm 3.4$ & $263 \pm 3.6$ & $264 \pm 3.0$ & $270 \pm 3.0$ & - \\
\hline $\mathrm{BW}^{0.75}(\mathrm{~kg})$ & $65.7 \pm 0.6$ & $65.3 \pm 3.6$ & $65.4 \pm 0.3$ & $66.6 \pm 0.6$ & - \\
\hline \multicolumn{6}{|l|}{ Intakes (g/kg BW $0.75 /$ day) } \\
\hline Dry matter & 82.0 & 83.7 & 82.8 & 81.8 & 1.08 \\
\hline Organic matter & 70.0 & 72.1 & 72.6 & 72.0 & 0.92 \\
\hline Neutral detergent fibre & 59.5 & 57.9 & 57.9 & 56.3 & 2.44 \\
\hline \multicolumn{6}{|l|}{ Apparent digestibility $(\mathrm{g} / \mathrm{g})$} \\
\hline Dry matter & 0.54 & 0.53 & 0.55 & 0.54 & 0.02 \\
\hline Organic matter & 0.56 & 0.56 & 0.58 & 0.57 & 0.02 \\
\hline Neutral detergent fibre & $0.38^{\mathrm{b}}$ & $0.44^{\mathrm{a}}$ & $0.47^{\mathrm{a}}$ & $0.47^{\mathrm{a}}$ & 0.02 \\
\hline \multicolumn{6}{|l|}{ Nitrogen balance } \\
\hline $\mathrm{N}$ intakes $\left(\mathrm{g} / \mathrm{kgBW}^{0.75} / \mathrm{day}\right)$ & 1.26 & 1.35 & 1.33 & 1.31 & 0.02 \\
\hline $\mathrm{N}$ faeces $\left(\mathrm{mg} / \mathrm{kg} \mathrm{BW} \mathrm{BW}^{0.75} /\right.$ day) & $928^{a}$ & $805^{\mathrm{b}}$ & $715^{\mathrm{c}}$ & $757^{\mathrm{bc}}$ & 29.5 \\
\hline $\mathrm{N}$ in the urine $\left(\mathrm{mg} / \mathrm{kg} \mathrm{BW} \mathrm{BW}^{0.75} /\right.$ day $)$ & $109^{c}$ & $134^{\mathrm{ab}}$ & $149^{\mathrm{a}}$ & $126^{\mathrm{b}}$ & 8.51 \\
\hline N-balance (mg/kg BW ${ }^{0.75} /$ day) & $218^{\mathrm{b}}$ & $412^{\mathrm{a}}$ & $468^{\mathrm{a}}$ & $431^{\mathrm{a}}$ & 29.7 \\
\hline \multicolumn{6}{|c|}{ Purine derivatives excretion in the urine $\left(\mathrm{mmo} / \mathrm{kgBW}^{0.75}\right)$} \\
\hline Allantoin & $0.206^{\mathrm{a}}$ & $0.183^{\mathrm{a}}$ & $0.175^{\mathrm{ab}}$ & $0.155^{\mathrm{b}}$ & 0.16 \\
\hline Uric acid & $0.036^{\mathrm{b}}$ & $0.040^{\mathrm{ab}}$ & $0.050^{\mathrm{a}}$ & $0.034^{\mathrm{b}}$ & 0.01 \\
\hline $\mathrm{PD}$ & $0.242^{\mathrm{a}}$ & $0.223^{\mathrm{ab}}$ & $0.226^{\mathrm{a}}$ & $0.188^{\mathrm{b}}$ & 0.02 \\
\hline PD/DOMI (mmol/kg DOMI) & $6.34^{\mathrm{a}}$ & $5.82^{\mathrm{a}}$ & $5.40^{\mathrm{ab}}$ & $4.60^{\mathrm{b}}$ & 0.54 \\
\hline
\end{tabular}

${ }^{\text {ab } V a l u e s}$ within the same row with the different superscripts are significantly $(\mathrm{P}<0.05)$ different and values within the same row without superscripts are not significantly $(\mathrm{P}>0.05)$ different; RTP: Oven-dried rain tree pod; RTPP: Oven dried RTP and premix; MLRT: Ovendried RTP, sundried mulberry leaves and premix; CLRT: Oven-dried RTP, sun-dried cassia leaves and premix; LLRT: Oven-dried RTP, sun-dried leucaena leaves and premix; SED: Standard error of difference

Source: Jetana et al. (2011)

In experiments 2, leucaena leaves were sun dried and were processed with $\mathrm{NaOH}$ and suns dried or were sun dried and added together with PEG when mixed in the supplement diet. The feed supplement composition is presented in Table 3.

The pattern of whole tract digestions in experiment 2 (Table 4) was similar to those in experiment 1. The NDF digestibility increased in animals fed treated leucaena supplemental diets. The digestibility coefficients of NDF (0.41 to 0.45$)$ improved when animals fed leucaena treated with $\mathrm{NaOH}$ diet, possibly due to the $\mathrm{NaOH}$ solution breaking down the lignin bond and the disintegration of fibre reduced particle size and the passage rates increased (Klopfenstein 1978) and sodium salts increased osmotic pressure and rumen washout (Jackson 1977). Likewise, the digestibility coefficients of NDF (0.41 to 0.46) increased in animals when fed leucaena + PEG diet, possibly sufficient rumen degradable protein (RDP) is available in the rumen due to tannins was inactive by PEG. It 
is possible that soluble carbohydrates in the rumen may decrease as it is binding with PEG (McSweeney et al. 2001; Brooker et al. 2000), this condition can elevate $\mathrm{pH}$ in the rumen, and this may be suitable to optimize cellulolytic microbial activity. Similar findings were reported by Silanikove et al. (1996); Waghorn et al. (1987); Barry et al. (1986), they found an increase in fibre digestibility of diet containing rich-tannins when supplemented with PEG.

Table 3. Composition of dietary supplements in experiment 2 ( $\mathrm{kg} /$ day/animal)

\begin{tabular}{lccc}
\hline \hline \multirow{2}{*}{ Ingredients $(\mathrm{g} / \mathrm{kg})$} & \multicolumn{3}{c}{ Supplements $(\mathrm{kg}$ on fed basis) } \\
\cline { 2 - 4 } & Control & $+\mathrm{NaOH}$ & $+\mathrm{PEG}$ \\
\hline Sun-dried leucaena & 2.00 & - & 2.00 \\
Sun-dried leucaena treated with $\mathrm{NaOH}$ & - & 2.00 & - \\
Oven-dried rain tree pod (RTP) & 1.78 & 1.78 & 1.78 \\
Cassava meal & 0.20 & 0.20 & - \\
Poly ethylene glycol (PEG) & - & - & 0.20 \\
Premix & 0.02 & 0.02 & 0.02 \\
\hline
\end{tabular}

Table 4 shows that the improvements of $\mathrm{N}$ balance in buffaloes fed leucaena + PEG diet may be due to the PEG binding with the phenolic compounds and tannins, resulting in the decrease of faecal $\mathrm{N}$ and urinary $\mathrm{N}$ excretions when compared to animals fed untreated leucaena supplements. This was in agreement with several workers (Waghorn \& Shelton 1997; Wang et al. 1996; Waghorn et al. 1987), who reported that the addition PEG in diet containing phenolic compounds usually increases the digestibility and availability of nutrients such as protein, carbohydrates and minerals, hence enhancing the values of $\mathrm{N}$ balance. The urine- $\mathrm{N}$ was higher in animal fed leucaena + PEG supplement than in those fed leucaena treated with $\mathrm{NaOH}$ diets, because the quantity of $\mathrm{N}$ intake having been slightly higher in those fed leucaena+PEG diet. However, the values of $\mathrm{N}$ excreted in feces were lower in animals fed leucaena + PEG supplements than those with other supplemental diet. This study indicated that proteins were bound with tannins before it appeared in the feces (Makkar et al. 1995), indicating that fewer excess fermentable $\mathrm{N}$ sources in the rumen were lost into the urine when animals fed diet containing tannins (Aerts et al. 1999). Nevertheless, the urinary $\mathrm{N}$ excretions decreased in animals fed both treated leucaena diets, but the faecal $\mathrm{N}$ increased in animal fed diet contained $\mathrm{NaOH}$ treated leucaena. This may be due to the $\mathrm{N}$ attached fibre in animals fed $\mathrm{NaOH}$ treated leucaena being excreted in the feces more than in those fed leucaena + PEG diet.

\section{Response of urinary PDs and the ratios PDs/DOMI}

The efficiency of the microbial $\mathrm{N}$ produced in the rumen was usually estimated by urinary PDs excretion and the ratios of PDs/DOMI. The microbial supply into the small intestine was lower in animals fed LLRT supplemental diet than in those fed the other supplemental diets (Table 4). One can expect that the formation of tannin-protein complexes when leucaena leaves are used as a feed in ruminants, the decrease of RDP (Waghorn et al. 1987) and consequently the ammonia- $\mathrm{N}$ concentration in the rumen might be limited and microbial production supply into the small intestine decreased (Waghorn 2008). The result of experiment 2 may indicate that the microbial supply into the intestine was higher in animals fed untreated leucaena diet than in those fed treated leucaena supplemental diets (Table 4). This could explain the PEG binding with tannins and 
carbohydrate (McSweeney et al. 2001; Brooker et al. 2000) in the rumen and later the RDP supply increased was not balanced with available energy supply (Puchala \& Kulasak 1992); therefore, microbial purine supply to the small intestine was low. However, the microbial yield supply to the small intestine decreases in animals fed leucaena treated with $\mathrm{NaOH}$ diet, accordingly the $\mathrm{NaOH}$ treated leucaena may not only decrease the phenolic compounds and tannins, but also reduce $\mathrm{N}$ and water soluble carbohydrates contents (SundstØl \& Owen 1984).

Table 4. Intakes of DM, OM and NDF and the digestibility coefficients of DM, OM, and NDF N balance, the urinary purine derivatives excretion and the ratios of allantoin/DOMI and Purine Derivatives (PD)/Digestible Organic Matter Intake (DOMI) in Thai swamp buffaloes fed a based diet of rice straw supplemented with different treated leucaena leaves

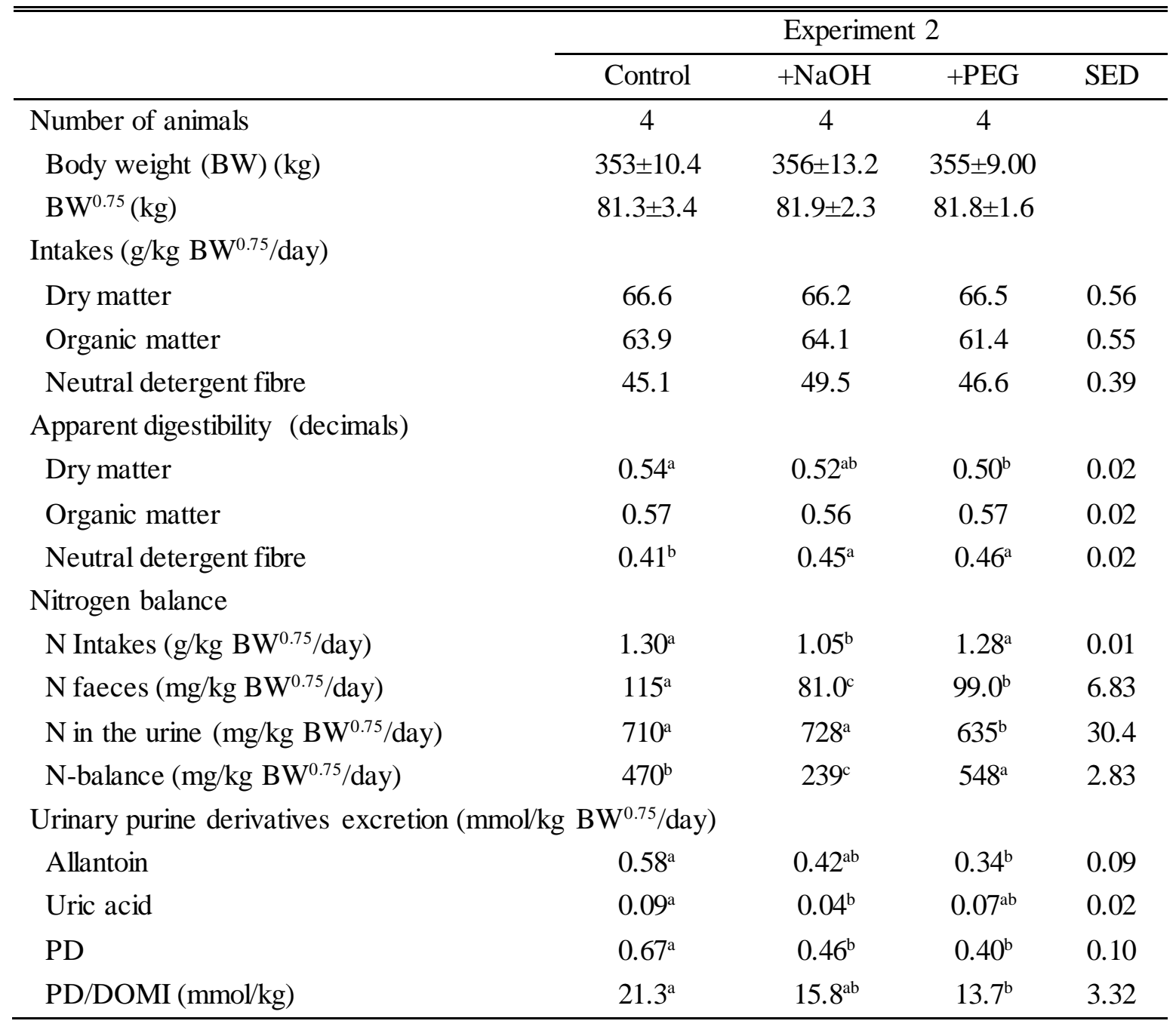

Control: Untreated sun-dried leucaena leaves; $+\mathrm{NaOH}$ : Sun-dried leucaena leaves treated with $\mathrm{NaOH}$ solution; +PEG: Untreated sun-dried leucaena leaves + polyethylene glycol (PEG); SED: Standard error of difference (least significant different $/ T_{\alpha 0.05}$ ); ${ }^{\text {ab }}$ Values within the same row with the different superscripts are significantly $(\mathrm{P}<0.05)$ different and values within the same row without superscripts are not significantly $(\mathrm{P}>0.05)$ different

Source: Jetana et al. (2011)

As consequence of the condensed tannins contents, these are still the main problem, if leucaena leaves is used as feedstuff in ruminants. Both treatments of leucaena by adding 
PEG and treating with $\mathrm{NaOH}$ solution to control tannins results in increasing fibre digestion. The use of $\mathrm{NaOH}$ solution treated leucaena are required chemicals, time of soaking and cost of $\mathrm{NaOH}$, though the $\mathrm{NaOH}$ might be replaced by ash wood for saving cost, but time and improvement of techniques still required. In the same way the addition of PEG in diets containing high phenolic compounds is a convenient method, but it increases cost. However, the form of untreated leucaena combined with RTP in the present study has shown enhancing microbial production supply into small intestine and $\mathrm{N}$ balance, but depressing fibre digestion. Thus, the further study is needed to find the best proportion between leucaena and RTP for achieving the optimum fibre digestion.

The study indicated the RTPP supplemental diet containing high sugar enhanced microbial supply to the small intestine. Other the hand, rain tree pod also can be used as an appetizing material for combination with leaves of luecaena, mulberry and cassia The use of $72^{\circ} \mathrm{C}$ oven temperature drying rain tree pod might be rather high to suitable for using it. Low fibre digestion in diet containing leuceana may be due to tannins contents. Sodium hydroxine $(\mathrm{NaOH})$ treatment and added PEG are ways of inactive tannins containing in the leucaena.

\section{Experiment 3}

The effects of Leucaena leucocephala added to ruzi grass in different proportions as mixed diets on purine derivatives and di-hydroxypyridine (DHP) in the urine of Thai Swamp Buffaloes was studied (Jetana et al. 2012).

Toxicity of leucaena in animals can be determined by two methods: (1) Direct methods, such as reduction of production, milk yield decreased, loss weight etc.; and (2) Indirect method, such as size of thyroid gland enlarge, lower hormone thyroxine in blood, the quantity of DHP in blood and urine. Earlier studies, the information of excretion of mimosine and DHP in the urine is a simple determination method to clarify that is the toxicity of leucaena in animals (host) in justifying being safe when animals gave leucaena in diet (Phaikaew et al. 2012; Jetana et al. 2010a). Though, leucaena can be fed at level $100 \%$ of dry matter intake in goats and did not show any sign of effects on animal health in Thailand (Phaikaew et al. 2012; Jetana et al. 2010a). However, the studies suggested that only certain proportion of leucaena in mixed diets, when fed to goats, its enhances intakes, digestion and microbial production in the rumen (Jetana et al. 2014, Jetana et al. 2016). The study therefore was conducted to investigate the effects of feeding different proportions of leucaena in mixed diets (leucaena vs ruzi grass (RZG (Bachiaria ruziziensis))) on purine derivatives and mimosine, 3, 4-DHP and 2,3-DHP in the urine.

\section{PDs excretion in the urine and the ratios of PDs: DOMI}

Table 5 shows that increased proportions of leucaena leaves to ruzi grass in mixed diet depressed PDs excretion in the urine (360, 393, 428 and $315 \mu \mathrm{mol} / \mathrm{kgBW}^{0.75}$, respectively) and the efficiency microbial digestion in buffaloes (17.10, 20.70, 27.30, and $18.06 \mathrm{mmol}$ PDs/kg DOMI, respectively) when compared to animals fed a based diet (551 $\mu \mathrm{mol}$ $\mathrm{PDs} / \mathrm{kgBW}^{0.75}$ and $\left.33.1 \mathrm{mmol} \mathrm{PDs} / \mathrm{kg} \mathrm{DOMI}\right)$. No difference in the efficiency microbial digestion in buffaloes, when animals fed the diet containing $75 \%$ of leucaena in mixed diet (27.3 mmol PDs/kg DOMI). The microbial yield in animals fed the mixed diets containing high proportions of leucaena were low, this is not surprising due to leucaena toxicity as a result of degradation of mimosine and DHP. Mimosine impedes cell division (Jones 1979), is acutely toxic and may cause rapid or violent deaths (Pratchett et al. 1991). According to Shelton (2009), mimosine toxicity is rare, due to mimosine usually being rapidly degraded 
by plant enzymes, certain unidentified members of the ruminal population and simple hydrogenation to the toxic goiterogen 3-hydroxy-4(1H)-pyridine (DHP). In addition, less protein contributed for microbial protein synthesis as a result of formation of tanninprotein complexes.

Table 5. Urinary purine derivatives excretion, the ratios of PD to DOMI urinary mimosine and DHP excretion in swamp buffalo fed a different proportion of ruzi grass and leucaena leaves

\begin{tabular}{|c|c|c|c|c|c|c|c|}
\hline & \multicolumn{5}{|c|}{ Proportions of leucaena level in the mixed diet } & \multirow{2}{*}{ SEM } & \multirow{2}{*}{$\mathrm{P}$-value } \\
\hline & $0 \%$ & $25 \%$ & $50 \%$ & $75 \%$ & $84 \%$ & & \\
\hline \multicolumn{8}{|l|}{$\mathrm{PD}$ in the urine $\left(\mu \mathrm{mol} / \mathrm{kg} \mathrm{BW} \mathrm{BW}^{0.75}\right)$} \\
\hline Allantoin & $373.00^{\mathrm{a}}$ & $231.00^{\mathrm{b}}$ & $248.00^{\mathrm{b}}$ & $291.00^{\mathrm{b}}$ & $216.00^{\mathrm{b}}$ & 49.70 & $<0.01$ \\
\hline Uric acid & $179.00^{\mathrm{a}}$ & $129.00^{\mathrm{ab}}$ & $145.00^{\mathrm{ab}}$ & $138.00^{\mathrm{ab}}$ & $99.20^{\mathrm{b}}$ & 44.40 & $<0.01$ \\
\hline $\mathrm{PD}$ & $551.00^{\mathrm{a}}$ & $360.00^{\mathrm{bc}}$ & $393.00^{\mathrm{bc}}$ & $428.00^{\mathrm{b}}$ & $315.00^{c}$ & 68.80 & $<0.01$ \\
\hline PD/DOMI & $33.10^{\mathrm{a}}$ & $17.70^{c}$ & $20.70^{\mathrm{bc}}$ & $27.30^{\mathrm{ab}}$ & $18.06^{\mathrm{bc}}$ & 6.76 & $<0.01$ \\
\hline Mimosine intake (g/day) & $0.00^{\mathrm{e}}$ & $34.60^{\mathrm{d}}$ & $68.50^{c}$ & $103.00^{\mathrm{b}}$ & $145.00^{\mathrm{a}}$ & 4.35 & $<0.01$ \\
\hline Mimosine intakes $\left(\mathrm{g} / \mathrm{kg} \mathrm{BW}^{0.75} \mathrm{~d}^{-1}\right)$ & $0.00^{\mathrm{e}}$ & $0.54^{\mathrm{d}}$ & $1.06^{\mathrm{c}}$ & $1.61^{\mathrm{b}}$ & $2.23^{\mathrm{a}}$ & 0.07 & $<0.01$ \\
\hline \multicolumn{8}{|c|}{ Mimosine and metabolites in the urine $\left(\mathrm{mg} / \mathrm{kg} \mathrm{BW} \mathrm{BW}^{0.75} /\right.$ day $)$} \\
\hline Mimosine & $0.00^{c}$ & $0.70^{\mathrm{b}}$ & $0.81^{\mathrm{b}}$ & $1.35^{\mathrm{a}}$ & $1.56^{\mathrm{a}}$ & 0.38 & $<0.01$ \\
\hline 3,4-DHP & $0.00^{\mathrm{c}}$ & $44.80^{c}$ & $194.00^{\mathrm{a}}$ & $111.00^{\mathrm{b}}$ & $208.00^{\mathrm{a}}$ & 37.30 & $<0.01$ \\
\hline 2,3-DHP & $0.00^{\mathrm{d}}$ & $15.30^{c}$ & $29.60^{\mathrm{a}}$ & $19.00^{\mathrm{bc}}$ & $24.70^{\mathrm{ab}}$ & 4.70 & $<0.01$ \\
\hline Mimosine+DHP & $0.00^{\mathrm{d}}$ & $60.80^{c}$ & 224.41 & 131.35 & 234.26 & 42.38 & $<0.01$ \\
\hline
\end{tabular}

BW $^{0.75}$ : Metabolic body weight; DHP: Dihydroxy pyridone; SEM: Standard error of mean;

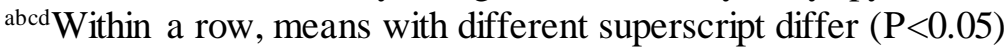

Source: Jetana et al. (2011)

\section{Mimosine and DHP excretion in the urine}

The mimosine and DHP rapidly appeared in the urine of buffalo after the ingestion of fresh leucaena about 1 h 20 min (Alcântara et al. 1997). The mimosine + DHP excretions in the urine of buffaloes increased with increasing proportions of leucaena in the diets. Animals consumed the mixed diet containing 25\% leucaena (LL) vs $75 \%$ ruzi grass, consequently the mimosine + DHP in the urine of buffaloes containing $60.8 \mathrm{mg}$ mimosine $+\mathrm{DHP} / \mathrm{kg} \mathrm{BW}{ }^{0.75}$. The value was below $100 \mathrm{mg}$ mimosine $+\mathrm{DHP} / \mathrm{kg} \mathrm{BW}^{0.75}$, this value is used to classify that subclinical toxicity is considered to be anticipated. The study demonstrated that mimosine and DHP toxicity in leucaena was more responsive in buffaloes fed the diet containing leucaena more $25 \%$ due to the mimosine + DHP in the urine was more $100 \mathrm{mg}$ mimosine+DHP/kg BW ${ }^{0.75}$. In short term feeding of this study, none of the animals showed any visible toxicity symptom during the period when different leucaena proportions in diets were fed.

The study demonstrated that there are benefits occur when combining leucaena with ruzi grass as a mixed diet. Leucaena did not cause toxicity to buffaloes when appropriate proportion of leucaena to ruzi grass was fed (not more $25 \%$ leucaena in the diet) and the mimosine+DHP in the urine were less $100 \mathrm{mg} / \mathrm{kg} \mathrm{BW} \mathrm{BW}^{0.75}$. 


\section{Experiment 4}

The effects of sun-dried rain tree pod pellets added to chopped fresh leucaena leaves in different proportions to form dietary supplements on purine derivatives and dihydroxypyridine (DHP) in the urine in Thai swamp buffaloes

While rain tree pod can be used as an appetizing material for combination with leaves of luecaena, mulberry and cassia in the previous study. Oven temperature at $72^{\circ} \mathrm{C}$ was used for drying rain tree pod, it may be rather too high to suitable for rain tree pod, thus the present study rain tree pods were sun dried. The pods of rain tree were firstly ground through a $10 \mathrm{~mm}$ grinding plate prior to grinding twice passing through an $6 \mathrm{~mm}$ grinding plate using 5-horsepower electrical meat grinder. The ground rain tree pods were sun dried for 12-18 $\mathrm{h}$ and later kept in air-tight storages. Previously, it was reported that animals consumed the mixed diet containing leucaena more 25\% (25\% Leucaena leucocephala (LL) vs $75 \%$ ruzi grass), indicating the mimosine + DHP was above $100 \mathrm{mg} / \mathrm{kg} \mathrm{BW}{ }^{0.75}$, therefore subclinical toxicity might consider to be anticipated. This is the experiment again studied that the border line between animals (host) and consumers (products) in justifying to be safe when we consumed the products obtaining from animals fed with leucaena diet.

This study thus was conducted to investigate the effects of short term feeding different proportions of sun-dried rain tree pellets mixed with chopped fresh leucaena leaves to form dietary supplements (sun-dried rain tree pod pellets Samanea saman (RTPP) vs chopped fresh leucaena leaves) on purine derivatives and mimosine, 3, 4-DHP and 2, 3-DHP in the urine. Before this experiment was conducted, the primary study had demonstrated that all experimental animals consumed only $6 \mathrm{~kg}$ chopped fresh leucaena leaves/day by dividing into two times, in the morning $3 \mathrm{~kg}$ and in the afternoon $3 \mathrm{~kg}$. The dietary supplements were prepared into four types by adding 300,600,1,100, and 1,600 $\mathrm{g}$ of sun-dried rain tree pellets (as fed basis) in each $3 \mathrm{~kg}$ fresh chopped leucaena leaves. The dietary supplements were fed twice a day and giving ad libitum ammoniated rice straw as basal diet in swamp buffaloes.

\section{PDs excretion in the urine and the ratios of PDs: DOMI}

Table 6 shows that the increased proportions of sun-dried RTPP in dietary supplements increased the purine derivatives in the urine $(2.16,2.04,2.33$, and 2.52 $\mathrm{mmol} / \mathrm{kg} \mathrm{BW} \mathrm{BW}^{0.75}$, respectively), but none of the efficiency microbial production in the rumen in buffaloes was affected by dietary supplement containing different sun-dried rain tree pellets $(55.7,52.8,59.2$ and $57.6 \mathrm{mmol} \mathrm{PDs} / \mathrm{kg}$ DOMI, respectively). It is noted that $\mathrm{PDs} / \mathrm{kg}$ DOMI ratios were higher than the previous results, when the exclusion rain tree pod into leucaena increased microbial production in the rumen.

\section{Mimosine and DHP excretion in the urine}

Table 6 shows that the urinary mimosine + DHP excretions increased in animals when the proportions of sun-dried RTPP in leucaena of dietary supplements increased. Though, the mimosine + DHP was nearly closed to $100 \mathrm{mg}$ mimosine $+\mathrm{DHP} / \mathrm{kg} \mathrm{BW}^{0.75}$ in the urine, but the average excretion rate of mimosine + 3,4-DHP did not reach to $100 \mathrm{mg}$ mimosine $+\mathrm{DHP} / \mathrm{kg} \mathrm{BW}^{0.75}$ in the urine. The mimosine + DHP in the urine was the lowest in buffaloes fed dietary supplement containing $300 \mathrm{~g}$ sun-dried RTPP $+3.0 \mathrm{~kg}$ luecaena $\left(75.5 \mathrm{mg} / \mathrm{kg} \mathrm{BW}{ }^{0.75}\right)$ than those fed the other dietary supplements $(87.9-93.8 \mathrm{mg} / \mathrm{kg}$ $\mathrm{BW}^{0.75}$ ). However, none of animals fed dietary supplement containing different proportions sun-dried RTPP in leucaena affected by 2,4-DHP in the urine. The present 
study, animals fed dietary supplements containing different proportions of sun-dried RTPP had not above the amount of $100 \mathrm{mg}$ mimosine $+\mathrm{DHP} / \mathrm{kg} \mathrm{BW}^{0.75}$ in the urine, therefore subclinical toxicity considered not to be anticipated to the animals. The study indicated sun-dried rain tree pod can be used as a good appetizing material for combination with leaves of leucaena. The present study showed that none the different proportions of RTPP affects to PDs/DOMI ratios, but the high proportions of RTPP in leuceana increased mimosine + DHP in the urine, but did not beyond $100 \mathrm{mg} / \mathrm{kg} \mathrm{BW}^{0.75}$.

Table 6. Urinary purine derivatives excretion, the ratios of PD to DOMI urinary mimosine and DHP excretion in swamp buffalo fed ad libitum of ammoniated rice straw and supplemented with the different proportions of rain tree pod pellets added into chopped fresh leucaena leaves

\begin{tabular}{lcccccc}
\hline \hline & $300 \mathrm{~g}$ & $600 \mathrm{~g}$ & 1,100 \\
RTPP & RTPP & $\begin{array}{c}1,600 \mathrm{~g} \\
\text { RTPP }\end{array}$ & RTPP & SEM & P-value \\
& & & & \\
\hline Purine derivatives in the urine $\left(\mathrm{mmol} / \mathrm{kg} \mathrm{BW}^{0.75} /\right.$ day) & & & & \\
Allantoin & $1.46^{\mathrm{bc}}$ & $1.41^{\mathrm{c}}$ & $1.65^{\mathrm{b}}$ & $1.87^{\mathrm{a}}$ & 0.106 & $<0.01$ \\
Uric & $0.71^{\mathrm{a}}$ & $0.63^{\mathrm{b}}$ & $0.68^{\mathrm{ab}}$ & $0.65^{\mathrm{ab}}$ & 0.036 & $<0.01$ \\
Total PD & $2.16^{\mathrm{bc}}$ & $2.04^{\mathrm{c}}$ & $2.33^{\mathrm{ab}}$ & $2.52^{\mathrm{a}}$ & 0.117 & $<0.01$ \\
PD/DOMI (mmol/kg) & 55.70 & 52.80 & 59.20 & 57.60 & 4.142 & $<0.01$ \\
Mimosine and metabolites in the urine $\left(\mathrm{mg} / \mathrm{kg}\right.$ BW $\left.{ }^{0.75} / \mathrm{day}\right)$ & & & & \\
Mimosine & $4.65^{\mathrm{b}}$ & $9.41^{\mathrm{a}}$ & $1.37^{\mathrm{c}}$ & $4.00^{\mathrm{bc}}$ & 1.430 & $<0.01$ \\
3,4-DHP & $18.20^{\mathrm{b}}$ & $20.90^{\mathrm{b}}$ & $28.70^{\mathrm{a}}$ & $28.20^{\mathrm{a}}$ & 1.886 & $<0.01$ \\
2,3-DHP & 52.60 & 57.60 & 60.90 & 61.70 & 6.143 & $<0.01$ \\
\hline Total DHP & $70.80^{\mathrm{b}}$ & $78.50^{\mathrm{ab}}$ & 89.70 & $89.80^{\mathrm{a}}$ & 7.120 & $<0.01$ \\
\hline Mimosine + DHP & $75.50^{\mathrm{b}}$ & $87.90^{\mathrm{ab}}$ & 91.10 & $93.80^{\mathrm{a}}$ & 6.812 & $<0.01$ \\
\hline
\end{tabular}

BW $^{0.75}$ : Metabolic body weight; DHP: Dihydroxy pyridone; SEM: Standard error of mean;

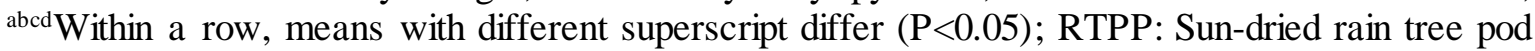
pellet; 300 g RTPP: $300 \mathrm{~g}$ sun-dried rain tree pod pellet $+3.0 \mathrm{~kg}$ chopped fresh leucaena leaves; 600 g RTPP: $600 \mathrm{~g}$ sun-dried rain tree pod pellet $+3.0 \mathrm{~kg}$ chopped fresh leucaena leaves; $1,100 \mathrm{~g}$ RTPP: $1,100 \mathrm{~g}$ sun-dried rain tree pod pellet $+3.0 \mathrm{~kg}$ chopped fresh leucaena leaves; $1,600 \mathrm{~g}$ RTPP: $1,600 \mathrm{~g}$ sun-dried rain tree pod pellet $+3.0 \mathrm{~kg}$ chopped fresh leucaena leaves

Source: Jetana et al. (2011)

The rain tree pod can be used as an appetizing material for combination with leaves of luecaena, mulberry and cassia. However, the RTPP dietary supplement containing high sugar enhanced microbial supply to the small intestine when fed to animals. The low fibre digestion in dietary supplement containing leuceana may be due to tannins contents. Sodium hydroxine $(\mathrm{NaOH})$ treatment and added PEG are ways of inactive tannins containing in the leucaena. Toxicity of leucaena did not affect to buffaloes when appropriate proportion of leucaena to ruzi grass was fed, it demonstrated the dietary supplement containing leucaena not more $25 \%$ was the highest benefit for buffaloes as the mimosine + DHP in the urine was less $100 \mathrm{mg} / \mathrm{kgBW}^{0.75}$. The high proportions of RTPP in leuceana increased purine derivatives and mimosine + DHP in the urine, but none the different proportions of RTPP affects to PDs/DOMI ratios. The studies suggested that animals fed diet containing the proportion of leucaena above $25 \%$ in mixed diet (Jetana et al. 2014 and Jetana et al. 2016); it therefore might be anticipated as a subclinical toxicity. 
Thus, the benefits of incorporating leucaena in the diet achieved when toxicity in leucaena must be controlled (Shelton 2009) i.e. by limiting amount of intake, inoculating bacteria with high capable of degrading and detoxifying DHP into the rumen, treating with chemicals and supplementing with minerals: Fe, Mn, Zn etc. (Phaikaew et al. 2012).

\section{CONCLUSION}

Several studies demonstrated the use of leucaena as alternative feed supplement to enhance the quality of feeds in swamp buffaloes production improvement. The practical implication of this review, is that it would be benefit to the smallholder farmers to use leucaena, because it is not only to improve quality of feeds and reduce cost of feed, but also higher biodiversity when leucaena plantation results in a higher $\mathrm{N}$ retention in soils and a lower methane from the rumen fermentation releases into the atmosphere.

\section{ACKNOWLEDGEMENT}

These works were supported by Thai Government budget under the increasing efficiency of Food and Agricultural Production by a Nuclear Technology Project (Project Code EFF 01/50, 01/51, 03/53, and 06/58).

\section{REFERENCES}

Aerts RJ, Barry TN, McNabb WC. 1999. Polyphenols and agriculture: Beneficial effects of proanthocyanidins in forages. Agric Ecosyst Environ. 75:1-12.

Alcântara PB, Ferreira TA, Beisman DA, Pereira AMF. 1997. Qualitative evaluation of DHP (dihydroxypiridine) in the urine of buffaloes fed with leucaena. In: Proceedings XVIII international Grassland Congress, Winnipeg, Manitoba, and Saskatoon. Saskatchewan (Canada). p. 25-26.

Barry TN, Manley TR, Duncan SJ. 1986. The role of condensed tannins in the nutritional value of Lotus pedunculatus for sheep 4. Sites of carbohydrate and protein digestion as influenced by dietary reactive tannin concentration. Brit J Nutr. 55:123-137.

Brewbaker JL, Hylin JW. 1965. Variation in mimosine content among leucaena species and related mimosaceae. Crop Sci. 5:348-349.

Brooker JD, O'Donovan L, Skene I, Sellick G. 2000. Mechanisms of tannin resistance and detoxification in the rumen. In: Brooker JD, editor. Tannins in livestock and human nutrition. Proceedings of an International Workshop. Adelaide, 31 ${ }^{\text {th }}$ May- $2^{\text {nd }}$ June 1999. Canberra (Australia): ACIAR. p. 117-122.

Ghosh MK, Atreja PP, Buragohain R, Bandyopahyay S. 2007. Influence of short-term Leucaena leucocephala feeding on milk yield and its composition thyroid hormones enzyme activity and secretion of mimosine and its metabolites in milk of cattle. J Agri Sci. 145:407-414.

Hegarty MPR. Court RD, Christie GS, Lee CP. 1976. Mimosine in Leucaena leucocephala is metabolized to a goitrogen in ruminants. Aust Vet J. 52:490-495.

Hoover WH. 1986. Chemical factors involved in ruminal fiber digestion. J Dairy Sci. 62:27552766.

Howard H, O'Kiely P, Moloney AP, O'Mara FP. 2007. Intake, digestibility, N metabolism and growth in growing steers offered zero-grazed grass supplemented with sucrose. In: Agricultural Research Forum. Tullamore, March 12-13. Teagasc (Ireland). 
Jackson MG. 1977. Review article: The alkali treatment of rice straws. Anim Feed Sci Technol. 2:105-130.

Jetana T, Abdullah N, Halim RA, Jalaludin S, Ho YW. 1998. Effects of protein and carbohydrate supplementation on fibre digestion and microbial population of sheep. Asian-Aust J Anim. Sci. 5:510-521.

Jetana T, Peetanonchai B, Thongrauy S. 2016. Effects of Leucaena leucocephala in Mixed Diets on milk production, mimosine, di-hydroxypyridine (DHP) in the urine and milk and thyroid hormones in dairy goats. Thai J Vet Med V. 25:250-251.

Jetana T, Suthikrai W, Usawang S, Vongpipatana C, Sophon S. 2006. Apparent digestion, nitrogen balance, purine derivatives and blood metabolites in male Thai, swamp buffalo and Thai Brahman cattle when fed ad libitum with rice straw. Buffalo J. 3:195-206.

Jetana T, Thongruay S, Uswang S, Hengtrakulsin R. 2012. A comparative study on mimosine, 3, 4dihydroxy pyridine (3, 4-DHP) and 2, 3-dihydroxy pyridine (2, 3-DHP), purine derivatives (PD) excretion in the urine, thyroid hormone and blood metabolites profiles of Thai swamp buffalo (Bubalus bubalis) and Murrah buffalo (Bubalus bubalis). Trop Anim Health Prod. 44:887-897.

Jetana T, Usawang S, Vongpipatana C, Thongruay S, Sophon S. 2007. Effects of Leucaena leucocephala and Samanea saman on apparent digestibility and microbial nitrogen production in the rumen of Brahman cattle (Bos indicus) fed Pangola (Digitaria eriantha) hay as a basal diet. In: Hare MD, Wongpichet, $\mathrm{K}$, editors. Proceedings of an International Forage Symposium Forages: A Pathway to Prosperity for Smallholder Farmers. Ubon Ratchathani, $5^{\text {th }} 7^{\text {th }}$ March 2007, Ubon Ratchathani (Thailand): Ubon Ratchathani University. p. 362-363.

Jetana T, Usawang S, Vongpipatana C, Thongruay S, Sophon S. 2008. Effects of replacement of leucaena (Leucaena leucocephala) with rain tree pod (Samanea saman) as a protein-rich supplement for cattle production. In: Proceedings of the 46th Kasetsart University Annual Conference. Kasetsart, 29 ${ }^{\text {th }}$ January- $^{\text {st }}$ February 2008. Kasetsart (Thailand): Kasetsart University. p. 39-45.

Jetana T, Uswang S, Sophon S. 2010a. Using leucaena (Leucaena leucocephala) for livestock production improvement: The comparable reliability of test kit for the detection of bacteria (Synergistes jonesii) between the determination of leucaena toxic in the urine and the detection of bacteria in the rumen. In: Thai Veterinarians' Concern for Communities. Proceedings of the $4^{\text {th }}$ MUT Veterinary Annual Conferences 2010. Bangkok, 26 ${ }^{\text {th }}$ November 2010. Bangkok (Thailand): Faculty of Veterinary Medicine, Mahanakorn University of Technology. p. 73-81.

Jetana T, Uswang S, Thongrauy S, 2014. The effects of Leucaena leucaephala added to para grass in different proportions to form mixed diets on mimosine, di-hydroxypyridone (DHP) in urine, milk, thyroid hormones in dairy goats. In: Proceeding the $2^{\text {nd }}$ Asian-Australasian Dairy Goat Conference. Bogor, 25 th $^{\text {t }} 7^{\text {th }}$ April 2014. Bogor (Indonesia): IPB. p. 159-161.

Jetana T, Vongpipatana C, Thongruay S, Usawang S, Sophon S. 2010b. Apparent digestibility, nitrogen balance, ruminal microbial nitrogen production and blood metabolites in Thai brahman cattle fed a basal diet of rice straw and supplemented with some tropical protein-rich trees. Anim Feed Sci Technol. 23:465-474.

Jetana T, Vongpipatana C, Usawang, S, Thongruay S. 2011. The use of tropical protein-rich leaves as supplements to Thai swamp buffalo receiving a basal diet of rice straw and treated leucaena (Leucaena leucocephala). Trop Anim Health Prod. 43:57-67.

Jetana T, Soutirai W, Usawang S, Vongpipatana C, Sophon S, Liang JB. 2009. The effects of concentrate added to pineapple (Ananas comosus linn. Mer.) waste silage in differing ratios to form complete diets, on digestion, excretion of urinary purine derivatives and blood metabolites in growing, male, Thai, swamp buffaloes. Trop Anim Health Prod. 41:449-459. 
Jones RJ. 1979. The value of Leucaena lecocephala as a feed for ruminants in the tropics. World Anim Rev. 31:13-23.

Khalili H, Huhtanen P. 1991. Sucrose supplements in cattle given grass silage-based diet. 1. Digestion of organic matter and nitrogen. Anim Feed Sci Technol. 33:247-261.

Klopfenstein, T.J., 1978. Chemical treatment of crop residues. J. Anim. Sci., 46, 841-848

Makkar HPS, Borowy NK, Becker K, Degen A. 1995. Some problems in fiber determination of tannins-rich forage (Acacia saline leaves) and their implications in in vivo studies. Anim Feed Sci Technol. 55:67-76.

Masafu MM, Linington MJ. 2006. The effect of feeding varying levels of Leucaena leucocephala on intake and digestibility of low-quality forages in the highveld of South Africa. Afri J Range Forage Sci. 23:177-183.

Matras J, Bartle SJ, Preston RL. 1991. Nitrogen utilization in growing lambs: Effects of grain (starch) and protein sources with various rates of ruminal degradation. J Anim Sci. 69:339347.

McSweeney CS, Palmer B, McNeill DM, Krause DO. 2001. Microbial interactions with tannins: nutritional consequences for ruminants. Anim Feed Sci Technol. 82:227-241.

Ørskov ER. 1986. Starch digestion and utilization in ruminant. J Anim Sci. 63:1624-1633.

Phaikaew C, Suksaran W, Ted-Arsen J, Nakamanee G, Saichuer A, Seejudee S, Kotprom N, Shelton HM. 2012. Incidence of subclinical toxicity in goats and dairy cows consuming leucaena (Leucaena leucocephala) in Thailand. Anim Prod Sci. 52:283-286.

Pratchett D, Jones RJ, Syrch FX. 1991. Use of DHP-degrading rumen bacteria to overcome toxicity in cattle grains irrigated leucaena pasture. Trop Grassland. 25:268-274.

Puchala R, Kulasak GW. 1992. Estimation of microbial protein flow from the rumen of sheep using microbial nucleic acid and urinary excretion of purine derivatives. Can J Anim Sci. 712:821-830.

Shelton HM. 2009. Feeding leucaena to ruminants: How to solve problem of mimosine toxicity. In: Document of the presentation at Department of Livestock Development, 7 April 2009, ChaiUtsawaluk Building, Bangkok (Thailand): Department of Livestock Development, Ministry of Agriculture and Cooperation, Ratchatawi, Bangkok, Thailand.

Sheton HM. 2007. Adoption of tropical legume technology: An update on leucaena. In: Hare MD, Wongpichet K, editors. Forages: A Pathway to Prosperity for Smallholder Farmers. Proceedings of an International Forage Symposium. Ubon Ratchathani, 5 th $^{\text {th }}$ March 2007. Ubon Ratchathani (Thailand): Ubon Ratchathani University.p. 223-247.

Silanikove N, Gilboa N, Nir I, Perevolotsky A, Nitsan Z. 1996. Effect of a daily supplementation of polyethylene glycol on intake and digestion of tannin-containing leaves (Quercus calliprinos, Pistacia lentiscus and Ceratonia siliqua) by goats. J Agri Food Chem. 44:199-205.

Staples WG, Elevitch CR. 2006. Samanea saman (rain tree) Fabaceace (legume family). In: Elevitch CR, editor. Traditional Trees of Pacific Islands: Their Culture, Environment, and Use. p. 661-674.

Stewart CS. 1977. Factors affecting the cellulolytic activity of rumen contents. Appl Environ Microb. 33:497-502.

SundstØl F, Owen E. 1984. Straw and other fibrous by-products as feed. Amsterdam (Netherlands): Elsevier Science publications.

Waghorn GC, Shelton ID. 1997. The effects of condensed tannins in Lotus pedunculatus on the nutritive value of pasture for sheep. J Agric Sci. 128:365-372. 
Waghorn GC. 2008. Beneficial and detrimental effects of dietary condensed tannins for sustainable sheep and goat production-progress and challenges. Anim Feed Sci Technol. 147:116-139.

Waghorn GC, Ulyatt MJ, John A, Fisher MT. 1987. The effect of condensed tannins on the site of digestion of amino acids and other nutrients in sheep fed on Lotus corniculatus L. Brit J Nutri. 57:115-126.

Wang Y, Douglas GB, Waghorn GC, Barry TN, Foote AG, Purchas RW. 1996. Effect of condensed tannins upon the performance of lambs grazing Lotus corniculatus and Lucerne (Medicago sativa). J Agric Sci. 126: 87-98. 